\title{
Impact of COVID-19 on the Aviation Business in the Russian Federation
}

\section{Alfiya KUZNETSOVA}

1 Bashkir State Agrarian University, Ufa, Russia; alfia_2009@mail.ru

\begin{abstract}
The number of air travelers in the Russian Federation in 2020 decreased by 41.3\% against the level of 2019. Due to the Coronavirus pandemic, the share of international air travel with non-CIS countries dropped sharply to $29 \%$, the share of international flights with the countries of the near abroad decreased to $2.2 \%$. Despite the decrease in the number of domestic flights by $17 \%$, the share of the number of domestic passenger flights increased from $43.9 \%$ to $68.5 \%$. In Russia, in 2020 the leaders in passenger air transportation are three airlines: 1) Aeroflot (with a market capacity of $21 \%$ ), 2) Siberia (18\%), 3) low-cost airline Pobeda (13.2\%). According to our calculations, the economic losses of Russian airlines due to the pandemic amounted to 13.708 billion dollars (or $8.8 \%$ of airline losses on a global scale). Our analysis showed that there are two large aviation harbors in Russia - Moscow and St. Petersburg. They account for an average of $45-55 \%$ of the total number of flights in the country. Nine Russian airports account for $75 \%$ of air travel. In the near future, the development of all types of domestic tourism will continue the growth dynamics, which will contribute to the revitalization of the aviation business.
\end{abstract}

Keywords: air travel, passengers, Covid pandemic, losses, lost profits

JEL Classification: R40, R41

\section{Introduction}

One of the important spheres of the economy and human activity, thanks to which borders are erased in the world, and people acquire many personal communications, impressions, exchange knowledge and experience, expand their worldview, adopt the best traditions, relax, acquire competitive advantages, is the aviation industry that accompanies the external outbound and domestic tourism. Currently, there is a small number of works of scientists in the world in which the economic size of the loss of profits caused by the coronavirus pandemic in the aviation business would be calculated.

An analysis of the assessment of changes in passenger traffic in the world due to the Covid pandemic is given in the work of Iacus et al (2021). Trends in global changes in air traffic to identify different types and trends of transnational human mobility are presented in Gabrielli et al (2020).

The decline in economic activity in the world has negatively affected the tourism sector. The destructive power of the impact of the Covid pandemic on tourism development is detailed in the works of Kaushal and Srivastava (2021). In the course of their research, the authors state that vital knowledge for the industry includes: «the need for multi-skills and 
professional development of employees, an increased sense of hygiene, sanitation and related SOPs, optimism about the revival of the industry, the role of the media and the need for more preparedness for crises». Other authors argue that «the larger the tourism sector in a country, the more actively fiscal and monetary policy measures have been taken to mitigate the impact of the pandemic» (Khalid et al., 2021). Relationship management in the tourism supply chain to overcome epidemics is presented in Gonzalez-Torres et al. (2020). The impact of the pandemic on hospitality education explored in Ye and Law (2021). The impact of the pandemic on human health and performance has been investigated by Seghieri et al. (2021) as well as Wu et al. (2020).

Scientists from different scientific fields investigated the consequences of the impact of the coronavirus situation, both on the state of development of society, economy, tourism, as well as on the effectiveness of government measures taken (Mofijur et al., 2020; Hossain, 2021). A preliminary assessment of the consequences of the coronavirus situation on the economy is given in the work of the Chinese scientist Jin et al. (2020).

At the same time, the lack of information on the consequences of the coronavirus situation on the state of domestic and foreign air travel was the basis for this study.

\section{Methodology}

The work uses analytical and economic-statistical methods to study the analysis of the current situation in the field of aviation business. The information base of the study was compiled by the official data of the Federal Air Transport Agency of the Russian Federation. The main purpose of this article is to assess the loss of profits experienced by the aviation business due to the Covid-19 Pandemic. A temporary empirical analysis of the data due to inflationary processes can distort the real understanding of the situation in the industry; comparable indicators are taken over the past three years. At the first step, we identified significant seasonal fluctuations in the aviation business. At the second step of the study, we studied the structure of air transportation: international and domestic. At the third step of the research, we identified the leading airlines in the number of air traffic. At the fourth step, the degree of occupancy in passenger seats was assessed. In the fifth step of the study, we calculated the loss of profit due to imperfect flights due to self-isolation during the Covid-19 pandemic. At the sixth step of the research, we tried to assess the leading airports in terms of the number of air traffic in the country. At the seventh step, we assessed the capacity of the air transportation market at the airports of Moscow and St. Petersburg. At the eighth step of the study, the leading airports in terms of the number of air traffic were assessed. At the ninth step of the research, we assessed the loss of profits at one of the airports in Russia and compared them on a global scale.

\section{Results}

In 2018, as a whole, 206.6 million air passengers were registered in the Russian Federation, in 2019 - 220.9 million people, in 2020 - only 129.6 million people. The number of air travelers in the Russian Federation as a whole in the period from 2018 to 2020 decreased 
by $41.3 \%$. This was facilitated by the coronavirus pandemia. Also, it is important to say that there are seasonal fluctuations in this type of business. Seasonal nature by months of the year is associated with increased travel during the holidays, and, as a rule, in the warm season (Figure 1).

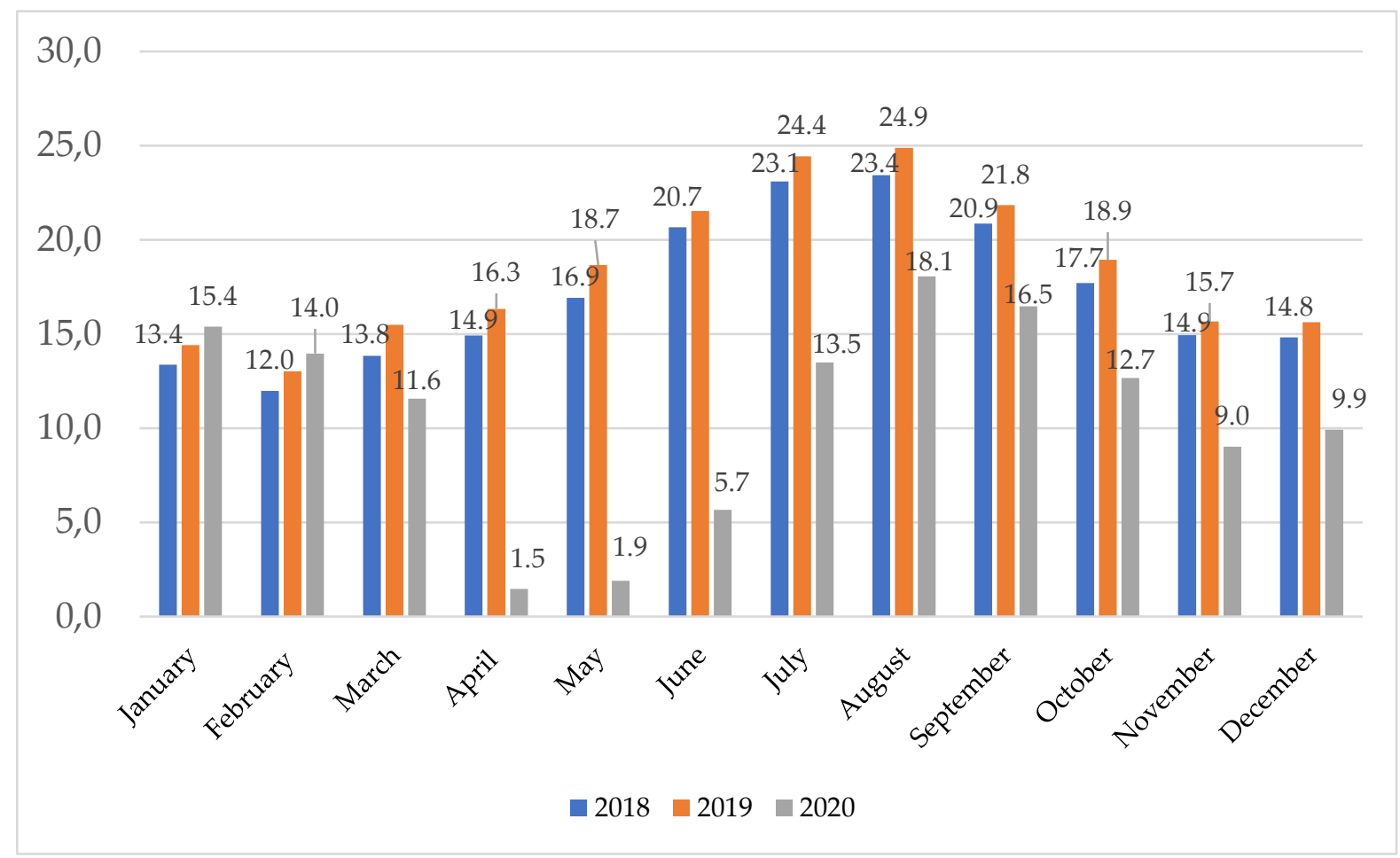

Figure 1. Schedule of seasonal fluctuations of air travel of passengers in the Russian Federation for the period from 2018 to 2020 (million people). Calculated by: The official website of the Official site of the Federal Air Transport Agency of the Russian Federation. Source: https://favt.gov.ru/ [Date of access: 15.01.2021]

In 2019, compared to 2018, the number of air flights in Russia increased by $6.9 \%$. This growth trend could continue in 2020, if not for the coronavirus infection that swept the whole world. In 2020, against the level of 2018, the reduction in the number of air flights was $37.3 \%$, in 2020 against the level of 2019, there was a record reduction in air flights in the country - by $41.3 \%$.

Analysis of the structure of air travel allows us to conclude that the share of international traffic in 2019 compared to 2018 increased by 3.4 percentage points. If it were not for the pandemic, we could observe a continuing trend of growth in the number of international air travel (Figure 2).

However, due to the coronavirus pandemic, the share of international air travel with non-CIS countries dropped sharply from $50.3 \%$ in 2018 to $29.3 \%$ in 2020 . The share of international flights with the countries of the Commonwealth of Independent States (former Soviet republics) decreased from $5.7 \%$ to $2.2 \%$, i.e. by 3.4 percentage points. During the pandemic, the number of domestic air travel decreased by $17 \%$ compared to 2018 , amounting to 105.2 million flights in 2020. At the same time, the share of the number of domestic passenger flights increased from $43.9 \%$ to $68.5 \%$, since by 24.9 percentage points. 
There are companies that are leaders in the air transportation market. Among Russian airlines, fourteen leaders should be noted in terms of the number of air traffic, which own more than $90 \%$ of all air flights in the country (Figure 3 ).

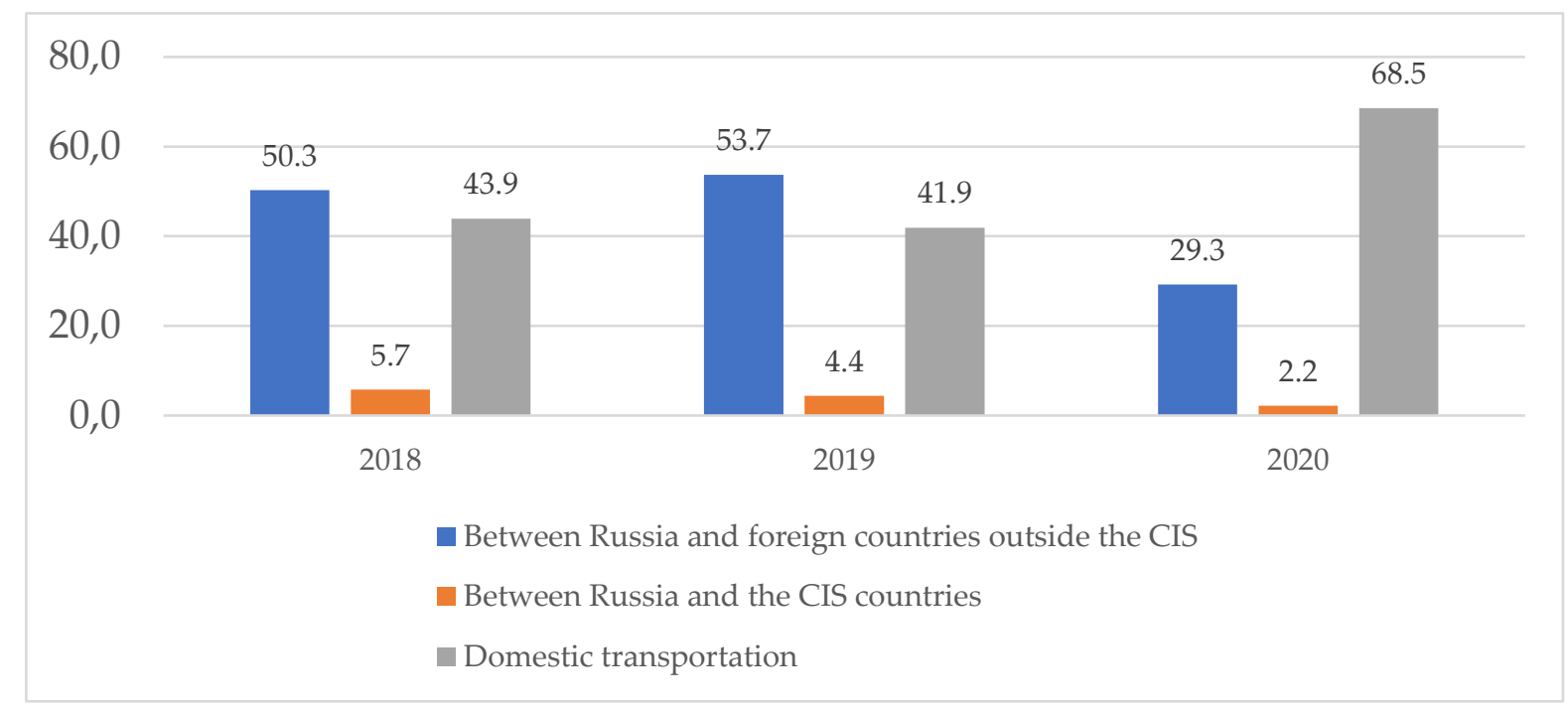

Figure 2. Structure of international and domestic flights in the Russian Federation (percentage). Calculated by: The official website of the Official site of the Federal Air Transport Agency of the Russian Federation. Source: https://favt.gov.ru/ [Date of access: 15.01.2021]

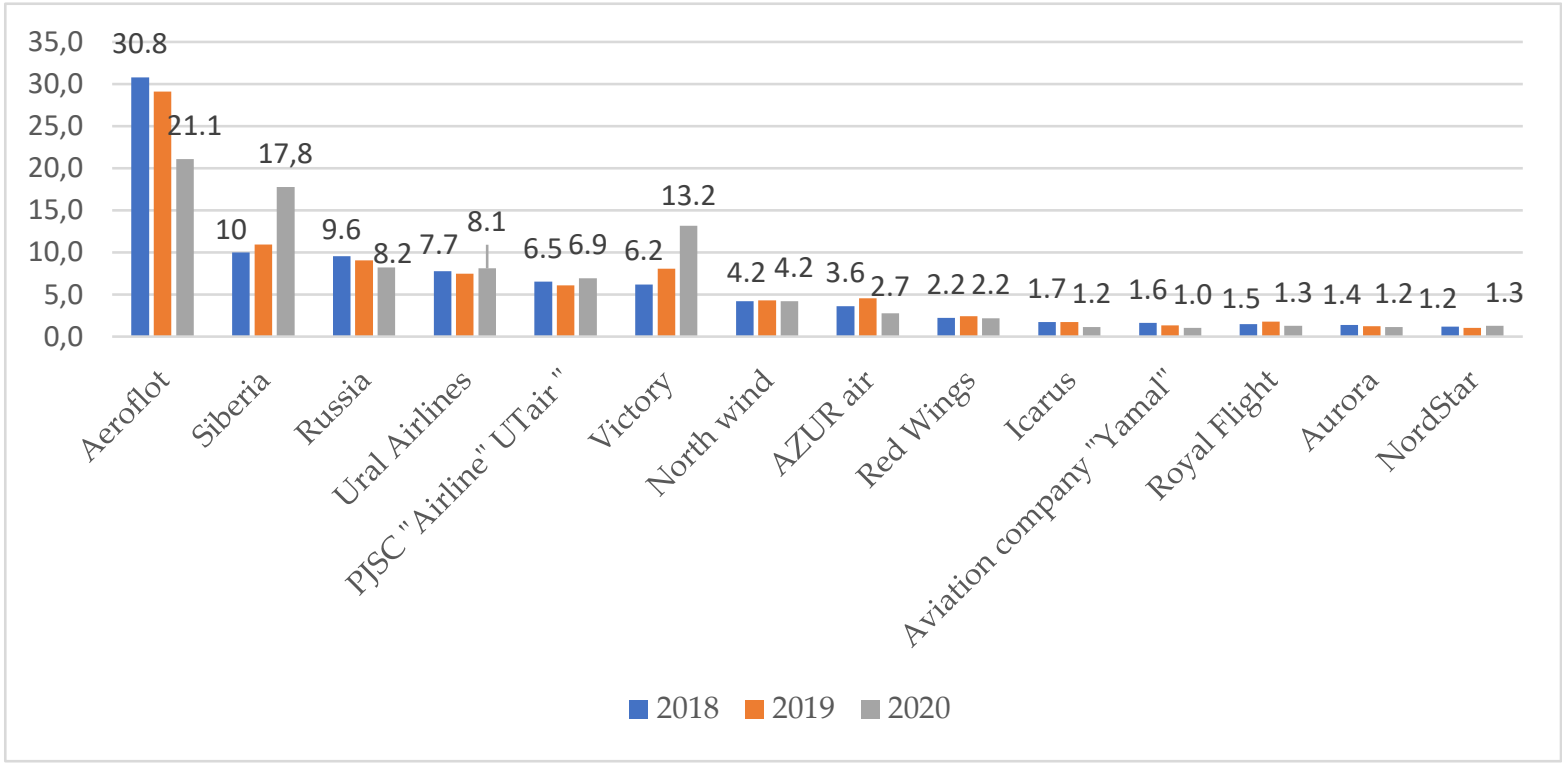

Figure 3. Share of the leading Russian airlines by the number of air traffic (percent). Calculated by: The official website of the Official site of the Federal Air Transport Agency of the Russian Federation. Source: https://favt.gov.ru/ [Date of access: 15.01.2021]

The share occupied by «Aeroflot», the leader in air transportation, decreased from $30.8 \%$ in 2018 to $21.1 \%$ in 2020. The share of «Siberia» airlines increased from 10\% in 2018 to $17.8 \%$ in 2020. The share of «Russia» airlines decreased from $9.6 \%$ in 2018 to $8.2 \%$ in 2020 . The share of «UTair» on the market increased slightly - from 6.5 to $6.9 \%$.

As for the rapid breakthrough, it was demonstrated by the «Pobeda» airlines. The capacity of the air travel market it covers increased from $6.2 \%$ to $13.2 \%$. During the pandemic, 
the low-cost airline «Pobeda» took third place in the country after «Aeroflot» and «Siberia» airlines, primarily due to unprecedented low prices for air tickets and $100 \%$ of flight load. This low-cost airline, which is a subsidiary of «Aeroflot», has proven to be in high demand, especially in the summer on the routes of flights to the Black Sea coast.

Low-cost airlines have a number of advantages: low cost, high safety: over the past ten years, there has been no fatal accident in the world, no baggage losses, punctual flights. The disadvantages are: non-refundable tickets, departures at uncomfortable times, random distribution of seats in the cabin, no indication of the seat in the boarding pass, lack of free meals on board, paid check-in at the airport counter, departures from minor airports, paid baggage transportation, cramped in the cabin (little space) and some others. Despite the possible disadvantages, the demand for low-cost airlines is quite high.

All airlines operating in the Russian market in 2020 saw not only a decrease in both the number of passengers carried and the share of the air transportation market coverage, but also a decrease in the share of passenger seats (Figure 4).

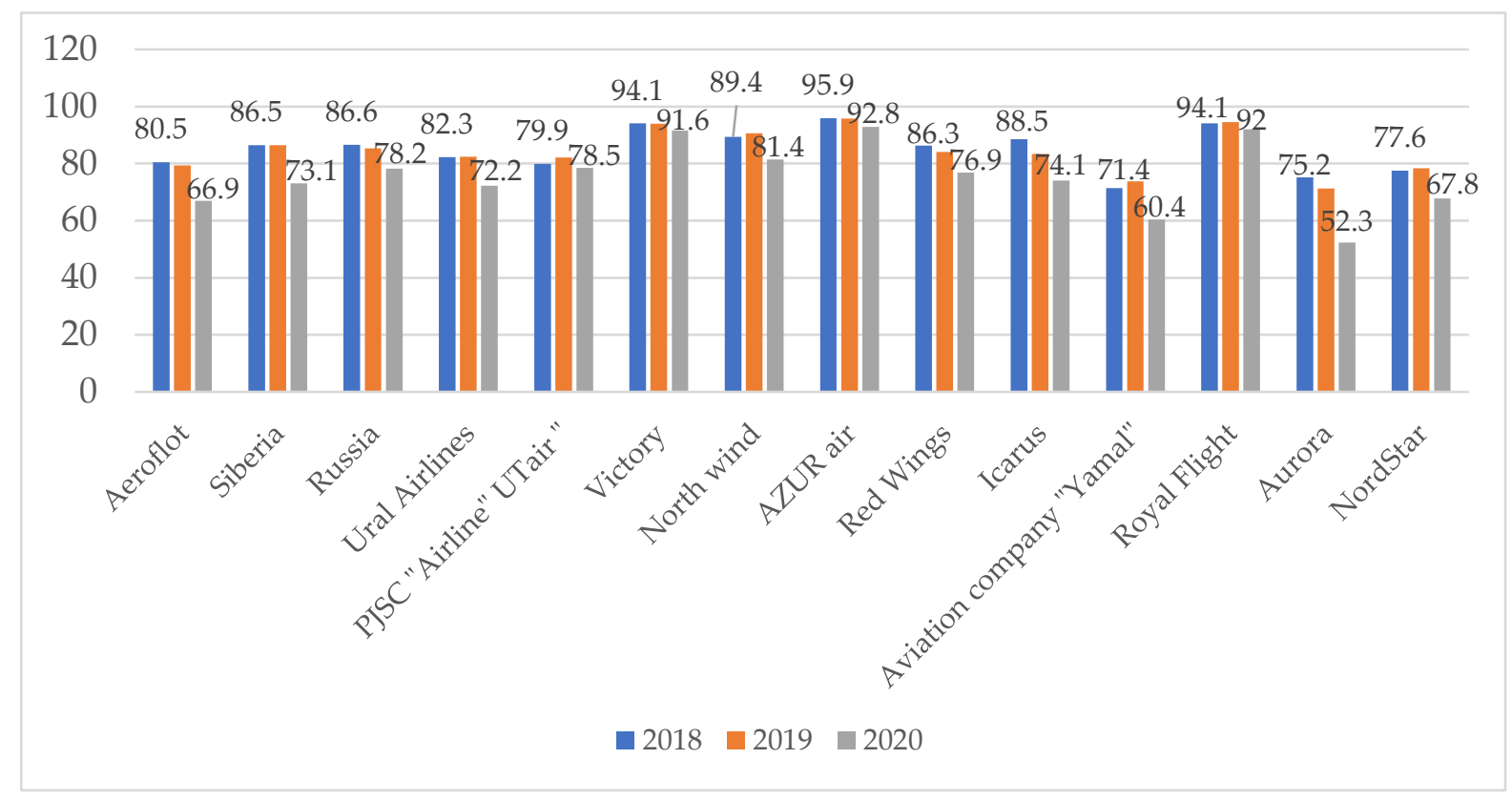

Figure 4. Passenger seat occupancy rate in Russian airlines (percent). Calculated by: The official website of the Official site of the Federal Air Transport Agency of the Russian Federation. Source: https://favt.gov.ru/ [Date of access: 15.01.2021]

The average monthly number of flights in 2018 was 17.2 million, in 2019 - 18.4 million, and in 2020 - only 10.4 million. Traditionally, the peak of the seasonal growth in the number of air travel falls in the period from June to October, i.e. for the vacation period.

People all over the world are so used to freedom of movement that the growth of the aviation business could rapidly gain momentum further. In January 2020, there was an increase in the number of flights by $6.8 \%$, in February - the growth was $7.3 \%$, but already in March, the number of flights by 2019 was $25.4 \%$, in April - by $91 \%$, in May - by $90 \%$, in June - by $73.7 \%$, in August - by $44.8 \%$, in September - by $24.8 \%$, in October - by 33.1\%, in November - by $42.5 \%$, in December - by $36.6 \%$. 
The fantastic reduction in the number of flights due to the coronavirus situation of Covid-19 has led to a significant loss in the industry. The crisis began to spread to related areas of activity: aircraft construction, airport operations, ground handling operators, trade, tourism. The rise in costs and the decline in revenues led to huge losses. According to our calculations, while maintaining the growth rate of the number of air flights at the level of the previous year, the hypothetical number of air flights, which should have taken place in 2020, was 236.3 million, and the actual - 129.6 million (which is $45.2 \%$ less, than expected) (Table 1 ).

Table 1. Calculation of the missed number of flights in the Russian Federation (million)

\begin{tabular}{|c|c|c|c|c|c|c|c|c|c|c|c|}
\hline Months & $\begin{array}{c}2018 \\
\mathrm{y} .\end{array}$ & $\begin{array}{c}2019 \\
\mathrm{y} .\end{array}$ & $\begin{array}{c}2020 \\
y .\end{array}$ & $\begin{array}{c}2020 \\
\text { to } \\
2018, \\
\text { in } \%\end{array}$ & $\begin{array}{c}2019 \\
\text { to } \\
2018, \\
\text { in } \%\end{array}$ & $\begin{array}{c}2020 \\
\text { to } \\
2019 \\
\text { in } \%\end{array}$ & $\begin{array}{c}\text { Must } \\
\text { it } \\
\text { would } \\
\text { be } \\
\text { in } 2020\end{array}$ & $\begin{array}{c}\text { Lost } \\
\text { benef } \\
\text { it } \\
\text { in } \\
2020\end{array}$ & $\begin{array}{l}\text { Lost } \\
\text { profits } \\
\text { in } \\
\text { rubles, } \\
\text { million } \\
\text { rubles. }\end{array}$ & $\begin{array}{l}\text { Lost } \\
\text { profit } \\
\text { s, } \\
\text { millio } \\
\text { n } \\
\text { euros }\end{array}$ & $\begin{array}{c}\text { Lost } \\
\text { profit } \\
\text { s, } \\
\text { millio } \\
\text { n } \\
\text { dollar } \\
\text { s }\end{array}$ \\
\hline January & 13.4 & 14.4 & 15.4 & 115.2 & 107.8 & 106.8 & 15.5 & -0.1 & 900.0 & 10.0 & 12 \\
\hline $\begin{array}{c}\text { Februar } \\
\mathrm{y}\end{array}$ & 12.0 & 13.0 & 14.0 & 116.7 & 108.8 & 107.3 & 14.2 & -0.2 & 1800.0 & 20.0 & 24 \\
\hline March & 13.8 & 15.5 & 11.6 & 83.6 & 112.0 & 74.6 & 17.4 & -5.8 & 52200.0 & 580.0 & 696 \\
\hline April & 14.9 & 16.3 & 1.5 & 9.8 & 109.5 & 9.0 & 17.9 & -16.4 & $\begin{array}{c}147600 . \\
0 \\
\end{array}$ & 1640.0 & 1968 \\
\hline May & 16.9 & 18.7 & 1.9 & 11.2 & 110.3 & 10.1 & 20.6 & -18.7 & $\begin{array}{c}168300 . \\
0 \\
\end{array}$ & 1870.0 & 2244 \\
\hline June & 20.7 & 21.5 & 5.7 & 27.4 & 104.2 & 26.3 & 22.4 & -16.8 & $\begin{array}{c}* 9,5= \\
159600 . \\
0\end{array}$ & 1774.1 & 2129 \\
\hline July & 23.1 & 24.4 & 13.5 & 58.4 & 105.8 & 55.2 & 25.9 & -12.4 & $\begin{array}{c}{ }^{*} 11= \\
136400 . \\
0\end{array}$ & 1516.5 & 1819 \\
\hline August & 23.4 & 24.9 & 18.1 & 77.0 & 106.2 & 72.6 & 26.4 & -8.4 & $\begin{array}{c}{ }^{*} 13= \\
109200 . \\
0\end{array}$ & 1213.8 & 1457 \\
\hline $\begin{array}{c}\text { Septemb } \\
\text { er }\end{array}$ & 20.9 & 21.8 & 16.5 & 79.0 & 104.7 & 75.4 & 22.9 & -6.4 & 57600.0 & 640.0 & 768 \\
\hline October & 17.7 & 18.9 & 12.7 & 71.5 & 106.9 & 66.9 & 20.2 & -7.6 & 68400.0 & 760.0 & 912 \\
\hline $\begin{array}{c}\text { Novemb } \\
\text { er }\end{array}$ & 14.9 & 15.7 & 9.0 & 60.3 & 104.9 & 57.5 & 16.4 & -7.4 & 66600.0 & 740.0 & 888 \\
\hline $\begin{array}{c}\text { Decemb } \\
\text { er }\end{array}$ & 14.8 & 15.6 & 9.9 & 66.8 & 105.4 & 63.4 & 16.5 & -6.6 & 59400.0 & 660.0 & 792 \\
\hline$\sum$ & 206.6 & 220.9 & 129.6 & 62.7 & 106.9 & 58.7 & 236.3 & -106.7 & $\begin{array}{c}1028000 \\
.0 \\
\end{array}$ & $\begin{array}{c}11424 . \\
4 \\
\end{array}$ & 13708 \\
\hline Change & - & - & - & -37.3 & +6.9 & -41.3 & - & - & & - & - \\
\hline
\end{tabular}

Calculated by: The official website of the Official site of the Federal Air Transport Agency of the Russian Federation. Source: https://favt.gov.ru/ [Date of access: 15.01.2021]

According to the official data of the Russian State News Agency, the average cost of air tickets departing in June was just over 9.5 thousand rubles, in July - just over 11 thousand rubles, and in August - about 13 thousand rubles (Tacc, 2020).

If in ordinary months (except for the summer months the average cost of one air flight on low-cost airlines is taken equal to 9,000 rubles, which is equivalent to 100 euros or 120 
dollars), then the cost of air travel in June will be about 105.6 euros (126.7 dollars), in July 122.3 euros (146.7 dollars), in August - 144.5 euros (or 173.4 dollars).

According to our calculations, the minimum number of passengers who could not make flights on the territory of the Russian Federation in 2020 is over 106.7 million, and the lost profits amounted to 1,028 billion rubles. (equivalent to $€ 11.424$ million or $\$ 13.708$ million).

According to the official data of the International Air Transport Association (IATA), which in June 2020 predicted losses for the airline in the world in the amount of $\$ 100$ billion, in November it became known that airlines are actually losing $\$ 157$ billion due to the worsening pandemic situation (Laurence, 2020).

As we noted above, according to our calculations, the losses of Russian airlines due to the pandemic amounted to 1,028.0 billion rubles, which is equivalent to 13.708 billion dollars. This means that the share of losses of Russian airlines on a global scale (from 157 billion dollars) is approximately $8.8 \%$.

It is important to note that there are two large aviation harbors in Russia - Moscow and St. Petersburg. They accounted for about 60 million air flights out of 129.6 million in the country in 2020, i.e. $46.3 \%$ (Figure 5).

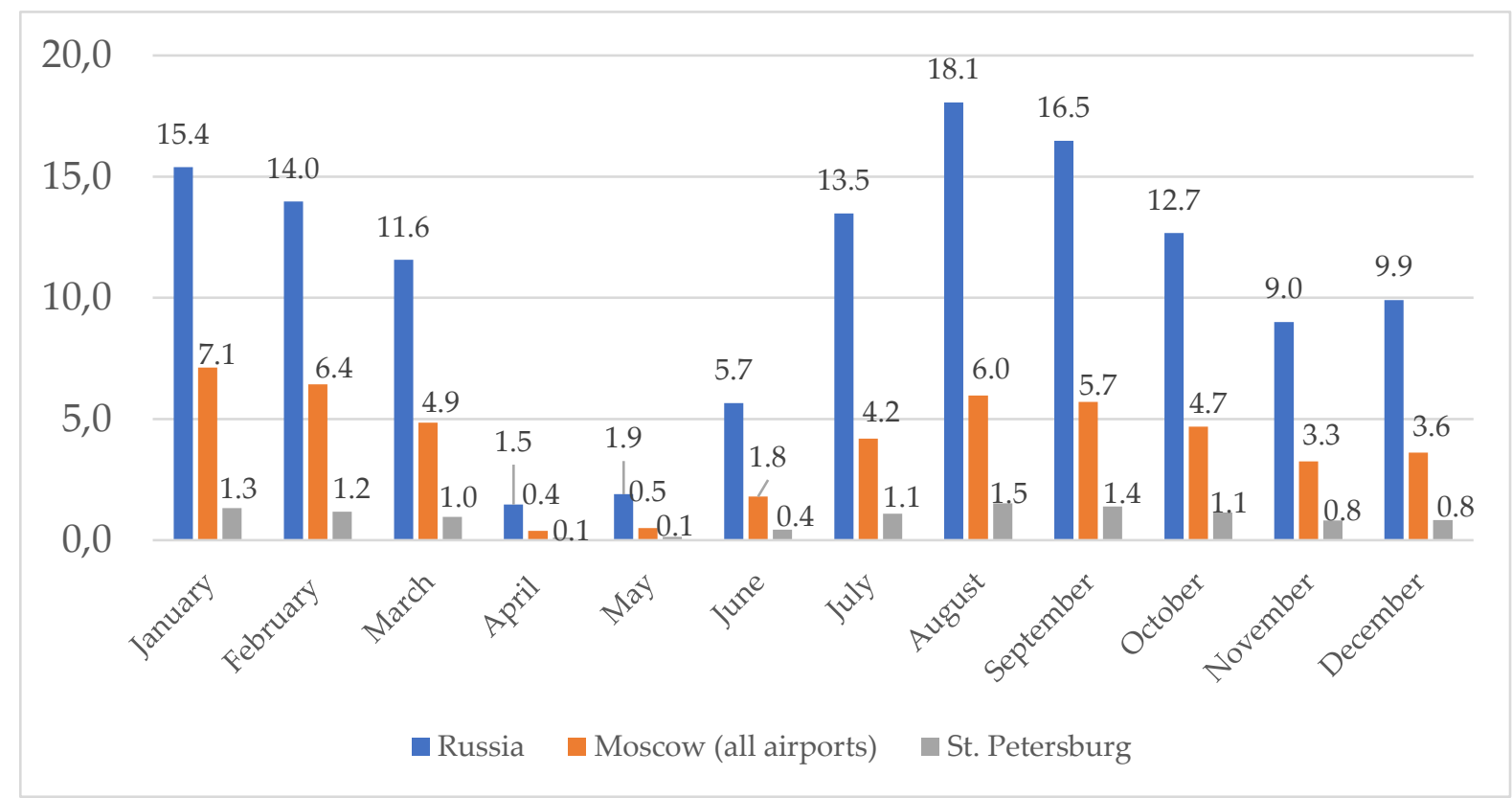

Figure 5. Number of air traffic in the Russian Federation, Moscow and St. Petersburg in 2020 (million people). Calculated by: The official website of the Official site of the Federal Air Transport Agency of the Russian Federation. Source: https:/favt.gov.ru/ [Date of access: 15.01.2021]

In January 2020, the number of flights to the "two capitals" of Russia was 8.4 million, in February - 7.6 million. In 2020, in March, the number of flights to Moscow and St. Petersburg was 5.9 million, in April - 0.5 million, in May - 0.6 million, in June - 2.2 million, in July - 5. 3, in August - 7.5, in September - 7.1, in October - 5.8, in November - 4.1, in December - 4.2 (Figure 6).

Thus, two Russian cities - Moscow and St. Petersburg - account for an average of 45-55\% of the total number of flights in the country. Before the start of the pandemic crisis, in January, Moscow and St. Petersburg accounted for $54.8 \%$ of the total number of flights in the country, 
and in February - 54.4\%. Despite the fact that in March the actual number of air flights decreased throughout the country, the share of the number of air flights to Moscow and St. Petersburg was 50.3\%, in April - 34.1\%, in May - 33.5\%, in June - 39.5\%, in July - $39.2 \%$, in August $-41.5 \%$, in September $-43.1 \%$, in October - $46 \%$, in November - $45.2 \%$, in December 44, 9\% (Figure 7).

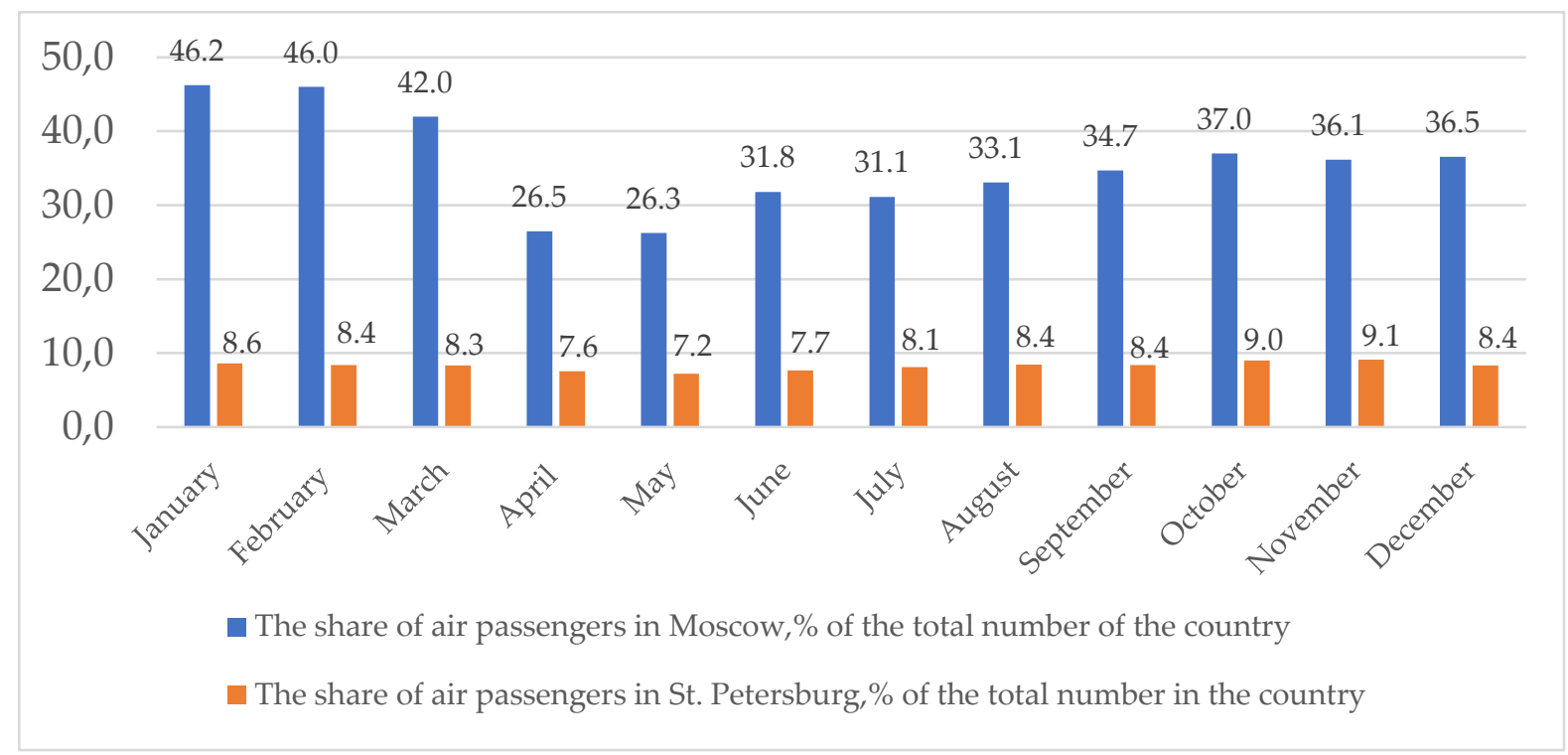

Figure 6. The share of passengers at the airports of Moscow and St. Petersburg (percent). Calculated by: The official website of the Official site of the Federal Air Transport Agency of the Russian Federation. Source: https://favt.gov.ru/ [Date of access: 15.01.2021]

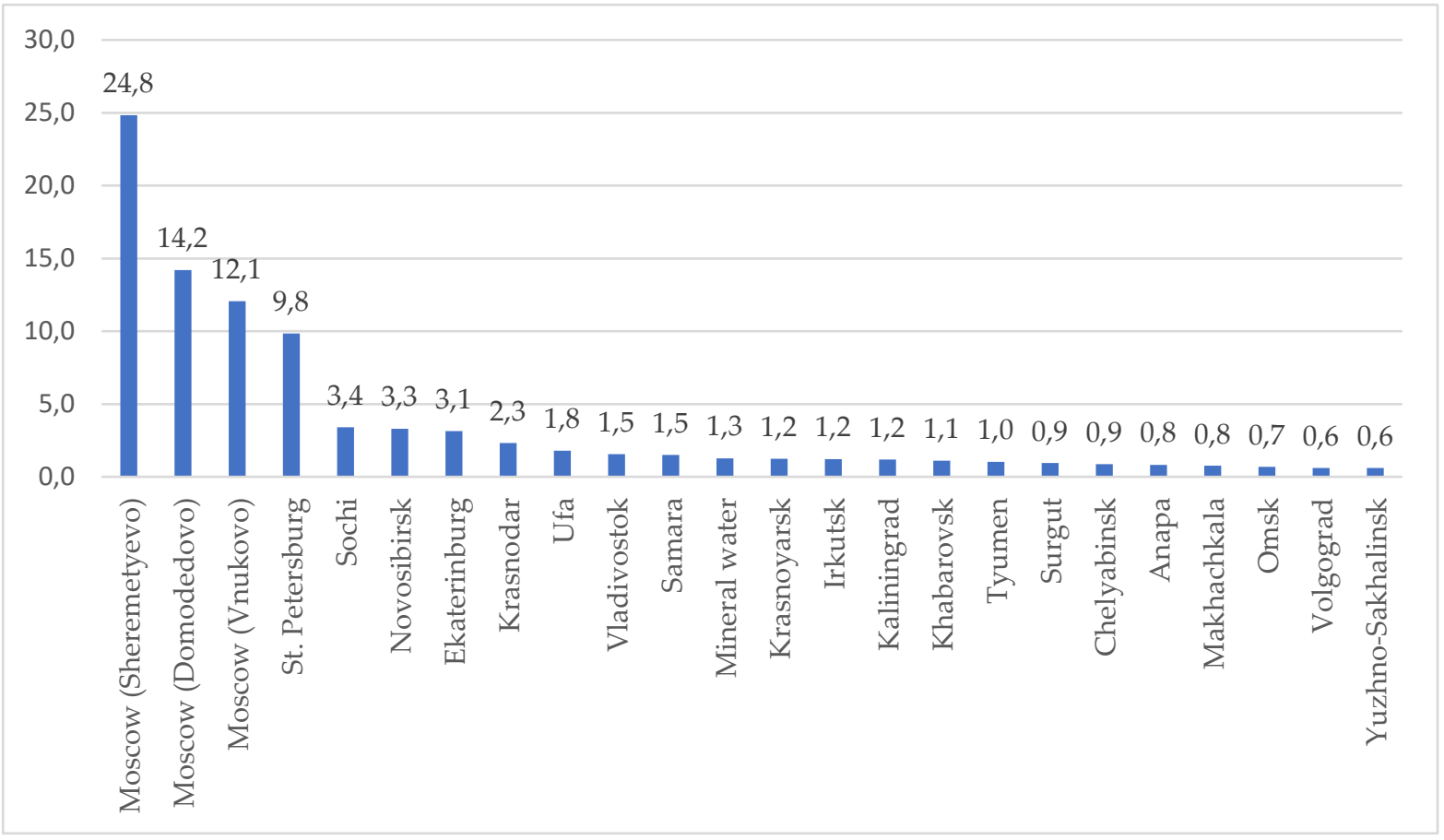

Figure 7. The share of air travel to the main airports of the Russian Federation (percentage). Calculated by: The official website of the Official site of the Federal Air Transport Agency of the Russian Federation. Source: https://favt.gov.ru/ [Date of access: 15.01.2021] 
More than $90 \%$ of air travel in the country falls on 24 Russian airports. The largest share of air flights falls on Moscow (Sheremetyevo airport) - 24.8\%, Moscow (Domodedovo airport) - 14.2\%, Moscow (Vnukovo airport) - 12.1\%, then St. Petersburg - 9.8\%, Sochi - 3.4\%, Novosibirsk - 3.3\%, Yekaterinburg - 3.1\%, Krasnodar - 2.3\%, Ufa - 1.8\%, airports in Vladivostok, Samara $-1.5 \%$ of air travel, Mineralnye water $-1.3 \%$, to the cities of Krasnoyarsk, Irkutsk, Kaliningrad - 1.2\% each, to Khabarovsk and Tyumen - 1\% each, Surgut - 0.9\%, Chelyabinsk - 0.9\%, Anapa and Makhachkala - 0.8\%, Omsk - 0.7, Volgograd - 0.6\%, Yuzhno-Sakhalinsk - $0.6 \%$.

Nine Russian airports account for $75 \%$ of air travel - these are: Moscow (Sheremetyevo), Moscow (Domodedovo), Moscow (Vnukovo), St. Petersburg, Sochi, Novosibirsk, Yekaterinburg, Krasnodar and Ufa.

Table 2. Seasonal number of air passenger movements at Ufa airport (thousand passengers)

\begin{tabular}{|c|c|c|c|c|c|c|c|c|c|c|c|c|c|}
\hline Indicators & Jan & Feb & Mar & Apr & May & Jun & Jul & Aug & Sept & Oct & Nov & Dec & $\Sigma$ \\
\hline 2018 & 220 & 198 & 216 & 229 & 290 & 323 & 342 & 344 & 314 & 272 & 235 & 240 & 3,223 \\
\hline 2019 & 237 & 205 & 246 & 253 & 322 & 340 & 367 & 368 & 339 & 322 & 276 & 282 & 3,557 \\
\hline 2020 & 275 & 253 & 227 & 32 & 55 & 135 & 225 & 278 & 266 & 232 & 177 & 214 & 2,369 \\
\hline $\begin{array}{c}\text { 2020/2018 } \\
\text { in } \% \\
\end{array}$ & 124.9 & 128.1 & 105.0 & 138 & 19.0 & 41.6 & 65.9 & 80.9 & 84.8 & 85.2 & 75.3 & 89.3 & 73.5 \\
\hline $\begin{array}{c}\text { 2020/2019 } \\
\text { in } \% \\
\end{array}$ & 116.0 & 123.4 & 92.3 & 12.6 & 17.1 & 39.7 & 61.3 & 75.5 & 78.5 & 72.0 & 64.1 & 75.9 & 66.6 \\
\hline $\begin{array}{c}\begin{array}{c}\text { Rate of } \\
\text { change }\end{array} \\
2020 \text { to } 2019 \\
(+/-)\end{array}$ & +38 & +48 & -19 & -221 & -267 & -205 & -142 & -90 & -73 & -90 & -99 & -68 & $-1,188$ \\
\hline $\begin{array}{c}\text { Average } \\
\text { ticket price, } \\
\text { USD }\end{array}$ & - & - & 120 & 120 & 120 & 126.7 & 122.3 & 173.4 & 120 & 120 & 120 & 120 & - \\
\hline $\begin{array}{l}\text { Lost profits, } \\
\text { thousand } \\
\text { USD }\end{array}$ & - & - & -2.280 & $-26,520$ & $-32,040$ & $-25,973.5$ & $-17,366.6$ & $\begin{array}{c}- \\
15,60 \\
6 \\
\end{array}$ & $-8,760$ & $-10,800$ & $-11,880$ & $-8,160$ & $159,386.1$ \\
\hline $\begin{array}{c}\text { Average } \\
\text { ticket price, } \\
\text { rubble }\end{array}$ & - & - & 9,500 & 9,500 & 9,500 & 95,000 & 11,000 & $\begin{array}{c}13,00 \\
0\end{array}$ & 9,500 & 9,500 & 9,500 & 9,500 & - \\
\hline $\begin{array}{c}\text { Average } \\
\text { ticket price, } \\
\text { million } \\
\text { rubble }\end{array}$ & - & - & -180.5 & $\begin{array}{c}- \\
2,099.5\end{array}$ & $\begin{array}{c}- \\
2,536.5\end{array}$ & $-19,475$ & $-1,562$ & $\begin{array}{c}- \\
1,170\end{array}$ & -693.5 & -855 & -940.5 & -646 & $-30,158.5$ \\
\hline
\end{tabular}

${ }^{1}$ Calculated by: The official website of the Official site of the Federal Air Transport Agency of the Russian Federation. Source: https://favt.gov.ru/ [Date of access: 15.01.2021]

Let us consider in more detail the consequences of the pandemic for the airport of one of the Russian cities - the city of Ufa (which is located in the Republic of Bashkortostan and is one of 85 Russian regions). Since 2007, one hundred percent of the shares of the Open Joint Stock Company "International Airport" Ufa "are 100\% owned by the Government of the Republic of Bashkortostan. The airport is one of the ten best international airports in the country, is a major transport and logistics hub connecting Europe and Asia. Thanks to the reconstruction of the airport in 2015 (in the amount of 1.6 billion rubles), it became possible 
to increase the capacity from 200 to 800 passengers per hour. In 2018, the volume of passenger traffic for the first time exceeded the number of 3 million people per year. In 2018, another reconstruction of the airport was carried out, which increased the capacity to 1.2 thousand people per hour.

The pandemic has made its insidious adjustments to the activities of the aviation business at the airport in Ufa. Consider the trends in seasonal fluctuations in air travel to the airport of Ufa for the period from 2018 to 2020 (Table 2).

According to our calculations, the losses of the aviation business of the Republic of Bashkortostan due to the Coronavirus pandemic amounted to about \$159.4 million (11.3 million rubles), which is $1.2 \%$ of the total losses of Russian airlines.

In 2018, the airport of the city of Ufa received and sent 3,223 thousand passengers, in $2019-3,557$ thousand, which is $10.4 \%$ more than in 2018. In 2020, the number of air flights decreased by $33.4 \%$ compared to 2019 and by $26.5 \%$ less than in 2018 (Figure 8).

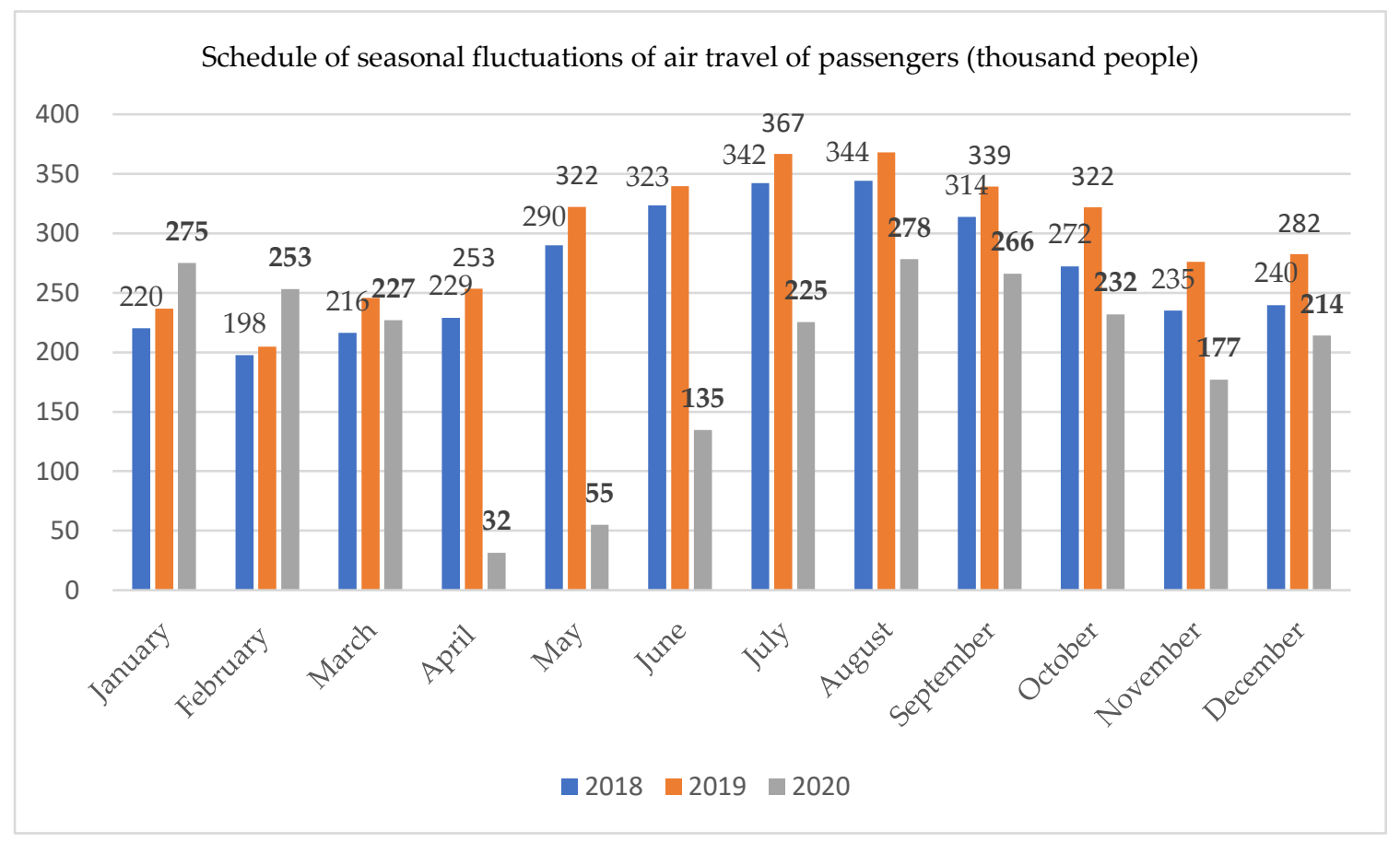

Figure 8. Schedule of seasonal fluctuations of air travel of passengers (thousand people). Calculated by: The official website of the Official site of the Federal Air Transport Agency of the Russian Federation. Source: https://favt.gov.ru/ [Date of access: 15.01.2021]

Just like on a national scale, in the regional aviation industry in January the increase in the number of air flights was 25\%, in February - by $127.8 \%$, in March - by $105.1 \%$. Since April, there has been a decrease in the number of air flights by $86 \%$, in May - by $90.6 \%$, in June - by $58.2 \%$, in July - by $34.2 \%$, in August - by $19.2 \%$, in September - by $15.3 \%$, in October - by $14.7 \%$, in November - by $24.7 \%$, in December - by $10.8 \%$.

The demand for domestic transportation was also limited by the self-isolation regime, the closure of hotels, resorts, restaurants, and places of mass recreation.

\section{Conclusions}

The conducted research allows us to draw the following conclusions: 
1. Air travel has been recognized as one of the most affected industries in Russia by the spread of COVID-19, as well as around the world. Due to the epidemic of the coronavirus situation, the number of people moving in the air transportation market in Russia, as well as throughout the world, has sharply decreased (by 90\%). Restrictions on flights led to a decrease in demand for related industries: aircraft construction, maintenance, lessors, ground handling.

2. The airports of Moscow and St. Petersburg occupy 45-55\% of the market share of all air transportation in Russia. These airports are the aviation hubs in the country. Due to the low profitability of interregional air transportation, many flights to nearby regions are made only through Moscow or St. Petersburg. Despite the pandemic, representatives of business travel are the main consumers of air travel.

3. Airlines carrying out international transportation received the greatest blow. These include the companies «Nord Wind», «AZUR air», «Icarus», «Red Wings», «Royal Flight», «Nord Star».

4. Airlines with a reduced risk to business should include those that receive government support measures: «Aeroflot», «S7», «Pobeda», «Aurora», «Yakutia», «Yamal».

5. The percentage of occupancy of air seats in 2019 on international flights was $85 \%$, on domestic routes - $82.6 \%$, on regional - 65\%. High service costs at regional airports, accompanied by long distance flights, as well as high flight underutilization lead to high operating losses, especially on domestic routes. Therefore, the main source of income for the industry has usually always been international shipping.

6. The reduction in the number of air travel has resulted in a reduction in the number of staff, which has led to an increase in one-time costs.

7. The reduction in the number of international air transportations and a slight increase in domestic air transportations do not compensate for the recovery of the situation in the industry, but significantly smooths out the financial losses.

8. According to our calculations, in 2020, the economic losses of Russian airlines due to the pandemic amounted to $1,028.0$ billion rubles, which is equivalent to 13.708 billion dollars (or $8.8 \%$ of airline losses on a global scale).

9. In response to the crisis, most of the aircraft fleet was stopped, flights were canceled. Representatives of the aviation business began to revise investment programs, cut marketing budgets, headcount, and working hours. The search for ways to solve the problems of paying taxes and tariffs with airports, as well as tax incentives and deferrals for mandatory payments, including credit payments, has intensified.

10. Government measures to mitigate the effects of the pandemic focused on providing interest-free payroll loans, deferral of taxes and insurance premiums, monthly payments to pay fixed costs of air carriers, and a moratorium on filing for bankruptcy. Taken together, all these support measures contributed to the preservation of the main professional staff, however, according to experts, it will take at least another 2-3 years to restore the economy of the aviation business.

\section{References}

Federal Air Transport Agency of the Russian Federation. (2021). The official website of the Official site of the Federal Air Transport Agency of the Russian Federation. https://favt.gov.ru/ 
Gabrielli, L., Deutschmann, E., Natale, F., Recchi, E., \& Vespe, M. (2020). Dissecting global air traffic data to discern different types and trends of transnational human mobility. Epj Data Science, 8(1). https://doi.org/10.1140/epjds/s13688-019-0204-x

Gonzalez-Torres, T., Rodriguez-Sanchez, J. L., \& Pelechano-Barahona, E. (2020) Managing relationships in the Tourism Supply Chain to overcome epidemic outbreaks: The case of COVID-19 and the hospitality industry in Spain. International journal of hospitality management, 92, 102733. https://doi.org/10.1016/j.ijhm.2020.102733.

Hossain, M. (2021) The effect of the Covid-19 on sharing economy activities. Journal of Cleaner Production, 280(1), 124782. https://doi.org/10.1016/j.jclepro.2020.124782

Iacus, S. M., Natale, F., Santamaria, C., Spyratos, S., \& Vespe, M. (2021) Estimating and projecting air passenger traffic during the COVID-19 coronavirus outbreak and its socio-economic impact. Safety Science, 129, 104791. https://doi.org/10.1016/j.ssci.2020.104791

Jin, H., Wang, H., Li, X., Zheng, W., Ye, S., Zhang, S., Zhou, J., \& Pennington, M. (2020) Economic burden of COVID-19, China, January-March, 2020: a cost-of-illness study. Bulletin of the World Health Organization, 99(2), 112-124. https://doi.org/10.2471/BLT.20.267112

Kaushal, V., \& Srivastava, S. (2021) Hospitality and tourism industry amid COVID-19 pandemic: Perspectives on challenges and learnings from India. International Journal of Hospitality Management, 92, 102707. https://doi.org/10.1016/j.ijhm.2020.102707

Khalid, U., Okafor, L. E., \& Burzynska, K. (2021) Does the size of the tourism sector influence the economic policy response to the COVID-19 pandemic? Current Issues In Tourism. https://doi.org/10.1080/13683500.2021.1874311

Laurence, F. (2020, November 24). Airlines are losing \$ 157 billion due to the worsening pandemic. https://www.reuters.com/article/us-airlines-iata/airlines-set-to-lose-157-billion-amid-worsening-slumpiata-idUSKBN2841KA?il=0

Mofijur, M., Fattah, I. M., Rizwanul, A., Md, A., Islam, A. B. M. S., Ong, H. C., Rahman, S. M. A., Najafi, G., Ahmed, S. F., Uddin, M. A., \& Mahlia, T. M. I. (2020) Impact of COVID-19 on the social, economic, environmental and energy domains: Lessons learnt from a global pandemic. Sustainable Production and Consumption, 26, 343359. https://doi.org/10.1016/j.spc.2020.10.016

Seghieri, C., La Regina, M., Tanzini, M., \& Tartaglia, R. (2021) Looking for the right balance between human and economic costs during COVID-19 outbreak. International journal for quality in health care: journal of the International Society for Quality in Health Care. https://doi.org/10.1093/intqhc/mzaa155

Tacc. (2020, July 9). Research: The cost of air tickets in Russia in the summer of 2020 decreased by $30 \%$. https://tass.ru/ekonomika/8919431

Wu, X. X., Yin, J., Li, C. L. Xiang, H. X., Lv, M., \& Guo, Z. Y. (2020) Natural and human environment interactively drive spread pattern of COVID-19: A city-level modeling study in China. Science of the Total Environment, 756, 143343. https://doi.org/10.1016/j.scitotenv.2020.143343

Ye, H. Y., \& Law, R. (2021) Impact of COVID-19 on hospitality and tourism education: a case study of Hong Kong. Journal of Teaching in Travel \& Tourism. https://doi.org/10.1080/15313220.2021.1875967 